\title{
PENGARUH SUHU PEMANASAN DAN KONSENTRASI CARBOPOL TERHADAP KARAKTERISTIK SABUN CAIR CUCI TANGAN
}

\author{
Ni Wayan Titin Kartika Sari, G. P. Ganda Putra*, Luh Putu Wrasiati \\ PS Teknologi Industri Pertanian, Fakultas Teknologi Pertanian, Universitas Udayana, Kampus Bukit \\ Jimbaran, Badung, Kode pos : 80361; Telp/Fax : (0361) 701801.
}

Diterima 24 Mei 2019 / Disetujui 03 Juli 2019

\begin{abstract}
Liquid soap is a liquid skin cleansing preparation made from basic ingredients of soap (potassium compounds with fatty acids from vegetable or animal oils). The purpose of this study was to determine the effect of heating temperature and carbopol concentration on the characteristics of hand washing liquid soap, as well as to determine the heating temperature and the best concentration of carbopol to produce hand washing liquid soap. This study used a factorial randomized block design with a 2-factor trial. The first factor is the heating temperature which consists of 3 levels are : $70^{\circ} \mathrm{C}, 80^{\circ} \mathrm{C}, 90^{\circ} \mathrm{C}$. The second factor is the concentration of carbopol which consists of 3 levels are: 1\%, 2\%, 3\%. The results showed that the heating temperature, carbopol concentration and interaction between the two treatments had a very significant effect on viscosity. Comparison of heating temperature has a very significant effect, but the concentration of carbopol and interaction between treatments has no significant effect on specific gravity and stability of foam. The ratio of carbopol concentration has a very significant effect, heating temperature has a significant effect but the interaction between the two treatments has no significant effect on the foam height. The treatment of heating temperature, carbopol concentration and interaction between treatments had no significant effect on water holding capacity, $\mathrm{pH}$, free alkali and overall reception. The best treatment was obtained from the treatment of $80^{\circ} \mathrm{C}$ heating temperature with $1 \%$ carbopol concentration.
\end{abstract}

Keywords: Heating temperature, carbopol concentration, saponification, liquid soap.

\begin{abstract}
ABSTRAK
Sabun cair merupakan sediaan pembersih kulit berbentuk cair dibuat dari bahan dasar sabun (senyawa kalium dengan asam lemak dari minyak nabati atau hewani). Tujuan penelitian ini adalah untuk mengetahui pengaruh suhu pemanasan dan konsentrasi carbopol terhadap karakteristik sabun cair cuci tangan, serta untuk menentukan suhu pemanasan dan konsentrasi carbopol terbaik untuk menghasilkan sabun cair cuci tangan. Penelitian ini menggunakan Rancangan Acak Kelompok faktorial dengan percobaan 2 faktor. Faktor pertama adalah suhu pemanasan yang terdiri dari 3 taraf yaitu: $70^{\circ} \mathrm{C}, 80^{\circ} \mathrm{C}$, $90^{\circ} \mathrm{C}$. Faktor kedua adalah konsentrasi carbopol yang terdiri dari 3 taraf yaitu: 1\%, 2\%, 3\%. Hasil penelitian menunjukan bahwa suhu pemanasan dan konsentrasi carbopol serta interaksi antar kedua perlakuan berpengaruh sangat nyata terhadap viskositas. Perlakuan suhu pemanasan dan interaksi antar kedua perlakuan berpengaruh sangat nyata terhadap bobot jenis dan stabilitas busa, tetapi konsentrasi carbopol berpengaruh tidak nyata. Perlakuan konsentrasi carbopol berpengaruh sangat nyata terhadap tinggi busa, tetapi konsentrasi carbopol dan interaksi antar kedua perlakuan berpengaruh tidak nyata.
\end{abstract}

*Korespondensi Penulis:

Email : gandaputra@unud.ac.id 
Perlakuan suhu pemanasan, konsentrasi carbopol dan interaksi antar perlakuan berpengaruh tidak nyata terhadap water holding capacity, $\mathrm{pH}$, alkali bebas dan penerimaan keseluruhan. Perlakuan terbaik diperoleh dari perlakuan suhu pemanasan $80^{\circ} \mathrm{C}$ dengan konsentrasi carbopol $1 \%$.

Kata kunci : Suhu pemanasan, konsentrasi carbopol, saponifikasi, sabun cair.

\section{PENDAHULUAN}

Sabun cair merupakan sediaan pembersih kulit berbentuk cair dibuat dari bahan dasar sabun (senyawa kalium dengan asam lemak dari minyak nabati atau hewani) atau deterjen dengan penambahan bahan yang diijinkan tanpa menimbulkan iritasi pada kulit (SNI, 1996). Sabun cair efektif untuk mengangkat kotoran yang menempel pada permukaan kulit, baik yang larut air maupun larut lemak (Castelyna, 2016). Sabun dalam bentuk cair dapat ditemui pada jenis produk, salah satunya sabun cair cuci tangan. Sabun cair cuci tangan merupakan cairan yang diformulasi untuk membantu membersihkan tangan dari kuman dan kotoran. Sabun cair cuci tangan dibuat melalui reaksi saponifikasi yang melibatkan asam lemak dari minyak dengan $\mathrm{KOH}$ (Mitzui, 1997).

Beberapa faktor yang mempengaruhi reaksi penyabunan dalam proses pembuatan sabun diantaranya konsentrasi $\mathrm{KOH} / \mathrm{NaOH}$, pengadukan, waktu dan suhu. Suhu menunjukkan derajat panas suatu benda. Pada proses saponifikasi, suhu merupakan hal yang penting untuk diperhatikan. Kenaikan suhu operasi akan meningkatkan konversi reaksi dari reaktan menjadi produk yang terbentuk. Akan tetapi kenaikan suhu yang berlebihan akan menurunkan konversi produk yang diinginkan (Kurnia, 2010). Suhu pemanasan pada saat pembuatan sabun dengan metode batch Cold-Process Saponification, biasanya berkisar antara $60^{\circ} \mathrm{C}-80^{\circ} \mathrm{C}$ (Dyartanti et al., 2014), pada penelitian dari (Oktari et al., 2017) suhu pemanasan pembuatan sabun berkisar antara $70-80^{\circ} \mathrm{C}$. Pada penelitian sebelumnya (Sukeksi et al.,2017) hasil terbaik diperoleh pada suhu $80^{\circ} \mathrm{C}$.
Selain minyak, dalam pembuatan sabun dibutuhkan bahan tambahan yang mampu memperbaiki mutu sabun antara lain pengental, pengisi, antioksidan, pewarna dan pewangi (Mabrouk, 2005). Dalam pembuatan sabun cair bahan tambahan yang memiliki peran penting untuk memperbaiki mutu sabun cair adalah pengental. Pengental berfungsi untuk mengentalkan sabun cair, bahan pengental yang biasa digunakan adalah CMC, carbopol, alginat dan turunan selulosa yang termodifikasi. Pada penelitian sebelumnya (Oktari et al. 2017) menggunakan larutan alginat sebagai bahan pengental pada pembuatan sabun cair cuci tangan, namun hasil yang diperoleh dari segi viskositas dan stabilitas busa menunjukkan bahwa sabun cair yang dibuat memiliki tingkat kekentalan dan stabilitas busa yang kurang maksimal. Hasil penelitian tersebut menunjukan bahwa hasil terbaik diperoleh dari sabun dengan bahan baku minyak kelapa sawit dengan konsentrasi alginat $1 \%$ dan memiliki nilai viskositas $500 \mathrm{mPas}$ sedangkan nilai viskositas dari sabun yang sudah dijual secara komersial dengan merk dagang Nosy memiliki viskositas $760 \mathrm{mPas}$ (Wijana et al., 2009). Dalam penelitian ini digunakan salah satu bahan pengental yang banyak digunakan yaitu carbopol.

Carbopol bersifat stabil dan higroskopik, penggunaan temperatur berlebih dapat mengakibatkan kekentalan menurun sehingga mengurangi stabilitas. Carbopol mempunyai viskositas antara $40.000-60.000$ $\mathrm{mPas}$ digunakan sebagai bahan pengental yang baik memiliki viskositasnya tinggi, menghasilkan gel yang bening. Carbopol digunakan untuk bahan pengemulsi pada konsentrasi $0,1-0,5 \%$ bahan pembentuk gel pada konsentrasi $0,5-2,0 \%$, bahan pensuspensi pada konsentrasi $0,5-1,0 \%$ dan 
bahan perekat sediaan tablet pada konsentrasi 5-10\% (Rowe et al.,2009). Pada penelitian Nurlina et al (2013) carbopol mempunyai kegunaan sebagai pengental untuk larutan topikal, dan konsentrasi carbopol untuk topikal $1 \%$ sampai $2 \%$. Hasil dari penelitian tersebut menunjukkan konsentrasi pengental carbopol $2 \%$ memiliki kestabilan fisik yang paling optimal. Peneilitian ini bertujuan untuk mengetahui pengaruh suhu pemanasan dan konsentrasi carbopol terhadap karakteristik sabun cair cuci tangan, serta untuk menentukan suhu pemanasan dan konsentrasi carbopol terbaik untuk menghasilkan sabun cair cuci tangan.

\section{METODE PENELITIAN}

\section{Tempat dan Waktu Kegiatan}

Penelitian ini dilakukan di
Laboratorium Rekayasa Proses dan
Pengendalian Mutu, Laboratorium Analisis
Pangan, Laboratorium Bioindustri Fakultas
Teknologi Pertanian, Universitas Udayana.
Waktu Pelaksanaan penelitian dimulai dari
Agustus sampai Oktober 2018.

\section{Bahan dan Alat Penelitian}

Bahan yang digunakan dalam proses pembuatan sabun cair adalah minyak kelapa dengan merk dagang Ikan Dorang yang diperoleh dari salah satu Supermarket di Denpasar, carbopol 940, KOH teknis, cocomidea, natrium benzoate dari toko bahan kue di Denpasar, asam stearat dari UD. Sabha Kimia, rivanol dari PT. Afi Farma, aquades, $\mathrm{HCl}$, Alkohol fenolftalein (indikator PP) dari Bratachem.

Peralatan yang digunakan dalam penelitian ini adalah timbangan digital (Mattler Toledo AB 204), hot plate magnetic sirer (C-MAG HS 7), viscometer broofield, gelas beker (Pyrex), gelas ukur ( Herma, Iwaki), thermometer, pipet volume, cawan petri, pH meter (Semlos 0,01), labu Erlenmeyer (Duran), tabung reaksi (Iwaki), piknometer (Iwaki), penggaris, spatula, label, tissue, aluminium foil, botol plastik, batang pengaduk, gelas plastik.

\section{Rancangan Percobaan}

Percobaan ini menggunakan rancangan acak kelompok (RAK) faktorial, dengan 2 faktor sebagai perlakuan. Faktor I yaitu suhu pemanasan yang terdiri dari 3 taraf yaitu: $\mathrm{S} 1=70^{\circ} \mathrm{C}, \mathrm{S} 2=80^{\circ} \mathrm{C}, \mathrm{S} 3=90^{\circ} \mathrm{C}$. Faktor II yaitu konsentrasi carbopol yang terdiri dari 3 taraf yaitu: $\mathrm{C} 1=1 \%, \mathrm{C} 2=2 \%, \mathrm{C} 3=3 \%$. Dari 2 faktor tersebut diperoleh 9 kombinasi perlakuan dan dikelompokan menjadi 2 kelompok sehingga didapat 18 unit percobaan. Data obyektif dianalisis dengan analisis varian (ANOVA), apabila terdapat pengaruh perlakuan terhadap parameter yang diamati, dilanjutkan dengan uji Duncan. Data variabel penerimaan keseluruhan sabun cair dianalisis dengan uji Friedmen non paramatrik. Penentuan perlakuan terbaik dari semua parameter, dilakukan dengan uji indeks efektivitas.

\section{Pelaksanaan Penelitian}

Pembuatan sabun cair cuci tangan dilakukan dengan tahapan yaitu, persiapan bahan baku pembuatan sabun kemudian dilakukan penimbangan bahan sesuai dengan formulasi yang telah ditentukan. Pemanasan minyak kelapa dan asam stearat dengan perbandingan tertentu pada gelas beker hingga mencapai suhu $70^{\circ} \mathrm{C}$ menggunakan hot plate. Selanjutnya ditambahkan larutan $\mathrm{KOH} 40 \%$ sedikit demi sedikit sambil dipanaskan hingga mencapai suhu 70,80 , $90^{\circ} \mathrm{C}$ (sesuai perlakuan) selama 2 jam hingga berbentuk pasta, suhu yang digunakan pada saat penelitian mengalami peningkatan suhu hingga $\pm 2^{\circ} \mathrm{C}$ dari suhu yang sudah ditentukan selama proses pemanasan berlangsung. Kemudian ditambahkan aquades, larutan carbopol 940 sesuai perlakuan, cocamid DEA kedalam pasta dan diaduk terus menerus hingga tercampur rata. Setelah itu, ditambahkan natrium benzoate dan rivanol ke 
dalam campuran dan diaduk hingga homogen menggunakan magnetic sirrer. Tahap terakhir dilakukan pengujian dan pengemasan produk sabun cair cuci tangan. Berikut formulasi sabun cair cuci tangan dapat dilihat pada Tabel 1 .

Tabel 1. Formulasi sabun cair cuci tangan (\%).

\begin{tabular}{|c|c|c|c|c|c|c|c|c|c|}
\hline \multirow{2}{*}{ Bahan } & \multicolumn{9}{|c|}{ Perlakuan } \\
\hline & S1C1 & S1C2 & S1C3 & S2C1 & $\mathrm{S} 2 \mathrm{C} 2$ & $\mathrm{~S} 2 \mathrm{C} 3$ & $\mathrm{~S} 3 \mathrm{C} 1$ & $\mathrm{~S} 3 \mathrm{C} 2$ & S3C3 \\
\hline $\begin{array}{l}\text { Minyak } \\
\text { Kelapa }\end{array}$ & 20 & 20 & 20 & 20 & 20 & 20 & 20 & 20 & 20 \\
\hline $\begin{array}{l}\text { Cocamide } \\
\text { DEA }\end{array}$ & 5 & 5 & 5 & 5 & 5 & 5 & 5 & 5 & 5 \\
\hline Carbopol 940 & 1 & 2 & 3 & 1 & 2 & 3 & 1 & 2 & 3 \\
\hline $\begin{array}{l}\text { Natrium } \\
\text { Benzoat }\end{array}$ & 0,5 & 0,5 & 0,5 & 0,5 & 0,5 & 0,5 & 0,5 & 0,5 & 0,5 \\
\hline Asam stearat & 1,5 & 1,5 & 1,5 & 1,5 & 1,5 & 1,5 & 1,5 & 1,5 & 1,5 \\
\hline $\mathrm{KOH} 40 \%$ & 10 & 10 & 10 & 10 & 10 & 10 & 10 & 10 & 10 \\
\hline Rivanol 0,1\% & 1 & 1 & 1 & 1 & 1 & 1 & 1 & 1 & 1 \\
\hline Ditambahkan & $\mathrm{Sd}$ & $\mathrm{Sd}$ & $\mathrm{Sd}$ & $\mathrm{Sd}$ & $\mathrm{Sd}$ & $\mathrm{Sd}$ & $\mathrm{Sd}$ & $\mathrm{Sd}$ & $\mathrm{Sd}$ \\
\hline Aquadest & 100 & 100 & 100 & 100 & 100 & 100 & 100 & 100 & 100 \\
\hline
\end{tabular}

Sumber : Novianti (2014) yang dimodifikasi

\section{Variabel yang Diamati}

Variabel yang diamati pada sabun cair cuci tangan adalah viskositas (Cottrell dan Kovaes, 1980), bobot jenis (SNI,1996), tinggi busa (Apgar,2010), stabilitas busa (Piyali et al., 1999), water holding capacity (Warta Konsumen, 1995 dalam Simanjuntak, 2000), pH (Depkes RI, 1995), alkali bebas (SNI, 1994), penerimaan keseluruhan (Susiwi, 2009).

\section{HASIL DAN PEMBAHASAN}

\section{Viskositas Sabun}

Hasil penelitian menunjukkan bahwa perlakuan suhu pemanasan, konsentrasi carbopol dan interaksi antar perlakuan berpengaruh sangat nyata $(\mathrm{P}<0,01)$ terhadap viskositas sabun cair cuci tangan. Nilai ratarata dari viskositas sabun cair cuci tangan dapat dilihat pada Tabel 2.

Tabel 2. menunjukkan bahwa adanya peningkatan nilai viskositas dengan adanya penambahan konsentrasi carbopol dan suhu pemanasan. Sabun cair yang menghasilkan nilai viskositas tertinggi adalah perlakuan suhu $90^{\circ} \mathrm{C}$ dan konsentrasi carbopol $3 \%$ dengan viskositas $3800 \mathrm{mPas}$ tidak berbeda dengan perlakuan suhu $80^{\circ} \mathrm{C}$ dengan viskositas $3600 \mathrm{mPas}$. Viskositas terendah dihasilkan dari perlakuan suhu $80^{\circ} \mathrm{C}$ dan konsentrasi carbopol $1 \%$ dengan viskositas 45 mPas tidak berbeda dengan perlakuan suhu $90^{\circ} \mathrm{C}$ dengan viskositas $50 \mathrm{mPas}$. Semakin tinggi konsentrasi carbopol dan semakin tinggi suhu pemanasan yang ditambahkan pada setiap perlakuan maka semakin tinggi nilai viskositas yang dihasilkan pada produk sabun cair cuci tangan.

Carbopol 940 dalam bentuk serbuk merupakan suatu polimer yang membentuk gulungan yang sangat erat (coiled) sehingga hal ini akan membatasi kemampuan thickening-nya, tetapi jika carbopol didispersikan ke dalam air, maka carbopol akan terhidrasi dan beberapa gulungannya akan terbuka (uncoiled) (Noveon, 2002). Polimer Carbopol 940 akan terjalin satu sama lain dengan membentuk cross link sehingga menghasilkan matriks tiga dimensi untuk membentuk gel yang sangat kental dalam waktu seketika (Suhaime et al., 2012). Semakin banyak polimer carbopol, maka 
pembentukan cross link semakin banyak yang mengakibatkan matriks gel yang terbentuk semakin banyak sehingga konsistensi sediaan gel pada suatu wadah Tabel 2. Nilai rata-rata viskositas (mPas) pada perlakuan suhu pemanasan dan konsentrasi carbopol.

\begin{tabular}{cccc}
\hline \multirow{2}{*}{ Konsentrasi Carbopol (\%) } & \multicolumn{3}{c}{ Suhu Pemanasan $\left({ }^{\circ} \mathrm{C}\right)$} \\
\cline { 2 - 4 } & 70 & 80 & 90 \\
\hline 1 & $55 \pm 7,07^{\mathrm{d}}$ & $45 \pm 21,21^{\mathrm{d}}$ & $50 \pm 14,14^{\mathrm{d}}$ \\
2 & $130 \pm 14,14^{\mathrm{cd}}$ & $575 \pm 35,36^{\mathrm{bc}}$ & $700 \pm 70,71^{\mathrm{b}}$ \\
3 & $425 \pm 35,36^{\mathrm{bcd}}$ & $3600 \pm 282,84^{\mathrm{a}}$ & $3800 \pm 282,84^{\mathrm{a}}$ \\
\hline
\end{tabular}

Keterangan: Huruf yang berbeda di belakang nilai rata-rata menunjukkan adanya perbedaan yang sangat nyata $(\mathrm{P}<0,01)$. Data merupakan rata-rata dari dua kelompok percobaan

Suhu pemanasan yang di tambahkan pada setiap perlakuan menunjukakan bahwa semakin tinggi suhu pemanasan, nilai viskositas semakin tinggi. Menurut Lachman (2008), sifat atau karakteristik gel dapat dipengaruhi karena efek suhu. Suhu dapat mempengaruhi struktur gel. Gel dapat terbentuk melalui penurunan temperatur tapi dapat juga terbentuk setelah pemanasan hingga suhu tertentu.

Standar umum kekentalan produk sabun cair yaitu 400-4000 mPas (Williams dan Schmitt, 2002 dalam Gandasasmita, 2009). Sabun cair cuci tangan yang memenuhi standar kekentalan sabun cair akan meningkat yang ditandai adanya peningkatan pada nilai viskositas (Ande, 2014).

Tabel 3. Nilai rata-rata bobot jenis $(\mathrm{g} / \mathrm{ml})$ pada perlakuan suhu pemanasan dan konsentrasi carbopol.

\begin{tabular}{ccccc}
\hline \multirow{2}{*}{ Konsentrasi Carbopol (\%) } & \multicolumn{3}{c}{ Suhu Pemanasan $\left({ }^{\circ} \mathrm{C}\right)$} & \multirow{2}{*}{ Rata-rata } \\
\cline { 2 - 5 } & 70 & 80 & 90 & $1,01 \pm 0,00^{\mathrm{a}}$ \\
2 & 1,02 & 1,01 & 1.01 & $1,01 \pm 0,00^{\mathrm{a}}$ \\
3 & 1,02 & 1,01 & 1,01 & $1,01 \pm 0,01^{\mathrm{a}}$ \\
\hline Rata-rata & 1,02 & 1,02 & 1,00 & \\
\hline
\end{tabular}

Keterangan: Huruf yang berbeda dibelakang nilai rata-rata pada baris atau kolom yang sama menunjukkan adanya perbedaan yang sangat nyata $(\mathrm{P}<0,01)$. Data merupakan rata-rata dari dua kelompok percobaan.

Tabel 3. menunjukkan bahwa adanya penurunan nilai bobot jenis dengan adanya penambahan suhu pemanasan. Sabun cair cuci tangan yang menghasilkan nilai tertinggi adalah perlakuan suhu $70^{\circ} \mathrm{C}$ dengan bobot jenis sebesar $1,02 \mathrm{~g} / \mathrm{ml}$. Bobot jenis terendah dihasilkan pada pelakuan suhu $90^{\circ} \mathrm{C}$ dengan bobot jenis sebesar $1,01 \mathrm{~g} / \mathrm{ml}$ tidak berbeda dengan perlakuan suhu $80^{\circ} \mathrm{C}$ dengan bobot jenis yang sama sebesar 1,01 $\mathrm{g} / \mathrm{ml}$. adalah perlakuan suhu pemanasan $70^{\circ} \mathrm{C}$ dengan konsentrasi carbopol 3\%, suhu pemanasan $80^{\circ} \mathrm{C}$ dengan konsentrasi carbopol $2 \%$ dan 3\% dan suhu pemanasan $90^{\circ} \mathrm{C}$ dengan konsentrasi carbopol $2 \%$ dan $3 \%$.

\section{Bobot Jenis}

Hasil penelitian menunjukkan bahwa suhu pemanasan berpengaruh nyata $(\mathrm{P}<0,05)$, sedangkan konsentrasi carbopol dan interaksi antar perlakuan berpengaruh tidak nyata $(\mathrm{P}>0,05)$ terhadap bobot jenis sabun cair cuci tangan. Nilai rata-rata bobot jenis sabun cair cuci tangan dapat dilihat pada Tabel 3 . 
kearah pereaksi atau dengan kata lain produk (sabun) akan berkurang (Kurnia,dkk.,2010).

Suhu pemanasan pada saat pembuatan sabun berkisar antara $60^{\circ} \mathrm{C}-80^{\circ} \mathrm{C}$ (Dyartanti et al., 2014). Hasil pengukuran bobot jenis sabun cair cuci tangan memiliki kisaran 1,01$1,02 \mathrm{~g} / \mathrm{ml}$ sesuai dengan Standar Nasional Indonesia (SNI 06-4085-1996) sabun cair yaitu $1,01-1,10 \mathrm{~g} / \mathrm{ml}$.

\section{Tinggi Busa}

Hasil penelitian menunjukkan bahwa konsentrasi carbopol berpengaruh sangat nyata $(\mathrm{P}<0,01)$, suhu pemanasan berpengaruh nyata $(\mathrm{P}<0,05)$, tetapi interaksi antar perlakuan berpengaruh tidak nyata $(\mathrm{P}>0,05)$ terhadap tinggi busa sabun cair cuci tangan. Nilai rata-rata tinggi busa sabun cair cuci tangan dapat dilihat pada Tabel 4.

Tabel 4 menunjukkan bahwa adanya penurunan tinggi busa dengan adanya penambahan konsentrasi carbopol. Sabun cair cuci tangan yang menghasilkan tinggi busa tertinggi adalah pada perlakuan suhu $90^{\circ} \mathrm{C}$ dan konsentrasi $1 \%$ dengan nilai tinggi busa sebesar $10,40 \%$. Tinggi busa terendah dihasilkan dari perlakuan suhu pemanasan $70^{\circ} \mathrm{C}$ dan konsentrasi carbopol 3\% dengan nilai tinggi busa pada sebesar $8,92 \%$.

Tabel 4. Nilai rata-rata tinggi busa $(\mathrm{cm})$ pada perlakuan suhu pemanasan dan konsentrasi carbopol.

\begin{tabular}{ccccc}
\hline Konsentrasi Carbopol (\%) & \multicolumn{3}{c}{ Suhu Pemanasan $\left({ }^{\circ} \mathrm{C}\right)$} & \multirow{2}{*}{ Rata-rata } \\
\cline { 2 - 4 } & 70 & 80 & 90 & \\
\hline 1 & 9,50 & 10,70 & 11,00 & $10,40 \pm 0,79^{\mathrm{a}}$ \\
2 & 9,50 & 10,00 & 10,25 & $9,92 \pm 0,38^{\mathrm{a}}$ \\
3 & 8,75 & 8,75 & 9,25 & $8,92 \pm 0,29^{\mathrm{b}}$ \\
\hline Rata-rata & $9,25 \pm 0,43^{\mathrm{b}}$ & $9,82 \pm 0,99^{\mathrm{ab}}$ & $10,17 \pm 0,88^{\mathrm{a}}$ \\
\hline
\end{tabular}

Keterangan: Huruf yang berbeda dibelakang nilai rata-rata pada baris atau kolom yang sama menunjukkan adanya perbedaan yang sangat nyata $(\mathrm{P}<0,01)$. Data merupakan rata-rata dari dua kelompok percobaan

Hasil penelitian menunjukan semakin tinggi konsentrasi carbopol maka nilai tinggi busa sabun semakin rendah dan semakin tinggi suhu pemanasan maka tinggi busa sabun semakin tinggi. Menurut Exerowa (1998), mekanisme pembentukan busa dimulai ketika gelembung gas masuk kedalam larutan surfaktan. Kemudian surfaktan akan terabsorpsi pada antarmuka gas/cairan dan terbentuk gelembung gas yang terbungkus oleh lapisan film atau busa. Busa ini akan cenderung naik kepermukaan karena berat jenis gas lebih kecil dari pada air. Namun pada permukaan cairan juga terdapat surfaktan yang terdapat pada lapisan batas air dan udara. Sehingga busa yang terbentuk tidak bisa lepas keluar udara, melainkan tetap tertahan pada batas permukaan cairan. Kemungkinan meningkatnya jumlah konsentrasi carbopol pada penelitian yang dilakukan dapat menahan busa karena massa jenis sabun lebih besar dibandingkan air.
Suhu pemanasan juga berpengaruh terhadap kadar busa yang dihasilkan pada penelitian ini, karena suhu dapat mempercepat suatu reaksi pada saat proses penyabunan (Derlean, 2009). Menurut Harry (1973) sediaan sabun memenuhi persyaratan tinggi busa yang dihasilkan berada pada kisaran 13-220 $\mathrm{mm}$ atau 1,3-22 $\mathrm{cm}$ (Apgar, 2010). Sabun cair cuci tangan yang dihasilkan pada penelitian menghasilkan tinggi busa sebesar 8,75-11 cm, sehingga dapat memenuhi syarat kisaran tingggi busa yang ditentukan.

\section{Stabilitas Busa}

Hasil penelitian menunjukkan bahwa suhu pemanasan berpengaruh sangat nyata $(\mathrm{P}<0,01)$, sedangkan konsentrasi carbopol dan interaksi antar perlakuan berpengaruh tidak nyata $(\mathrm{P}>0,05)$ terhadap stabilitas sabun cair cuci tangan. Nilai rata-rata stabilitas busa sabun cair cuci tangan dapat dilihat pada 
Tabel 5.

Tabel 5. Nilai rata-rata stabilitas busa (\%) pada perlakuan suhu pemanasan dan konsentrasi carbopol.

\begin{tabular}{lllll}
\hline Konsentrasi & \multicolumn{2}{l}{ Suhu Pemanasan $\left({ }^{\circ} \mathrm{C}\right)$} & \multirow{2}{*}{ Rata-rata } \\
\cline { 2 - 5 } Carbopol $(\%)$ & 70 & 80 & 90 & $72,91 \pm 4,75^{\mathrm{a}}$ \\
\hline 1 & 78,39 & 69,98 & 70,36 & $72,95 \pm 1,45^{\mathrm{a}}$ \\
2 & 74,37 & 73,00 & 71,48 & $72,96 \pm 2,22^{\mathrm{a}}$ \\
\hline 3 & 74,04 & 74,44 & 70,40 & \\
\hline Rata-rata & $75,60 \pm 2,43^{\mathrm{a}}$ & $72,47 \pm 2,27^{\mathrm{b}}$ & $70,75 \pm 0,63^{\mathrm{b}}$ & \\
\hline
\end{tabular}

Keterangan: Huruf yang berbeda dibelakang nilai rata-rata pada baris atau kolom yang sama menunjukkan adanya perbedaan yang sangat nyata $(\mathrm{P}<0,01)$. Data merupakan rata-rata dari dua kelompok percobaan.

Tabel 5 menunjukkan bahwa hasil penelitian dari perlakuan suhu pemanasan berpengaruh sangat nyata terhadap stabilitas sabun cair cuci tangan. Hasil penelitian menunjukkan nilai tertinggi dihasilkan pada perlakuan suhu $70^{\circ} \mathrm{C}$ dan konsentrasi carbopol 1\% dengan stabilitas busa 78,39\%. Stabilitas terendah dihasilkan dari perlakuan suhu $80^{\circ} \mathrm{C}$ dan konsentrasi carbopol $1 \%$ dengan stabilitas busa 69,98\%. Semakin tinggi suhu pemanasan maka stabilitas busa semakin menurun.

Menurut Fathurrahman et al., (2017) temperatur menyebabkan penurunan ketinggian busa menjadi lebih cepat atau dengan kata lain kestabilan busanya akan menurun, karena degradasi. Kriteria stabilitas busa yang baik yaitu apabila dalam waktu 5 menit (T5) diperoleh stabilitas busa antara 60-70\% (Deragon,1968 dalam Rozi, 2013).

\section{Water Holding Capacity}

Hasil penelitian menunjukkan bahwa suhu pemanasan, konsentrasi carbopol dan interaksi antar perlakuan berpengaruh tidak nyata $(\mathrm{P}>0,05)$ terhadap water holding capacity sabun cair cuci tangan. Nilai ratarata water holding capacity sabun cair cuci tangan dapat dilihat pada Tabel 6 .

Tabel 6. menunjukkan bahwa suhu pemanasan dan konsentrasi carbopol berpengaruh tidak nyata terhadap sabun cair cuci tangan. Sabun cair yang menghasilkan nilai water holding capacity cenderung tertinggi adalah pada perlakuan suhu $70^{\circ} \mathrm{C}$ konsentrasi carbopol $2 \%$ dengan jumlah rata- rata water holding capacity $7,57 \%$, sedangkan nilai terendah dihasilkan pada perlakuan suhu $80^{\circ} \mathrm{C}$ konsentrasi carbopol $2 \%$ dengan jumlah rata-rata water holding capacity $6,90 \%$. Water holding capacity yang tinggi pada suatu produk sabun cair dinyatakan sebagai kemampuan produk sabun cair dalam mempertahankan beratnya terhadap pengaruh sinar matahari.

Tabel 6. Nilai rata-rata water holding capacity (\%) pada perlakuan suhu pemanasan dan konsentrasi carbopol.

\begin{tabular}{ll}
\hline Perlakuan & Rerata \\
\hline $70^{\circ} \mathrm{C}$, Carbopol 1\% & $7,04 \pm 0,89^{\mathrm{a}}$ \\
$70^{\circ} \mathrm{C}$, Carbopol $\%$ & $7,56 \pm 0,78^{\mathrm{a}}$ \\
$70^{\circ} \mathrm{C}$, Carbopol 3\% & $7,48 \pm 0,79^{\mathrm{a}}$ \\
$80^{\circ} \mathrm{C}$, Carbopol 1\% & $7,15 \pm 0,77^{\mathrm{a}}$ \\
$80^{\circ} \mathrm{C}$, Carbopol $2 \%$ & $6,90 \pm 0,76^{\mathrm{a}}$ \\
$80^{\circ} \mathrm{C}$, Carbopol 3\% & $7,29 \pm 0,99^{\mathrm{a}}$ \\
$90^{\circ} \mathrm{C}$, Carbopol 1\% & $7,06 \pm 0,80^{\mathrm{a}}$ \\
$90^{\circ} \mathrm{C}$, Carbopol $2 \%$ & $7,50 \pm 0,78^{\mathrm{a}}$ \\
$90^{\circ} \mathrm{C}$, Carbopol 3\% & $7,46 \pm 0,79^{\mathrm{a}}$ \\
\hline
\end{tabular}

Keterangan: Huruf yang sama dibelakang nilai ratarata menunjukkan perbedaan yang tidak nyata $(\mathrm{P}>0,05)$. Data merupakan rata-rata dari dua kelompok percobaan.

Kehilangan berat yang kecil menandakan produk tersebut memiliki water holding capacity yang tinggi dan begitu pula sebaliknya. Dengan demikian nilai water holding capacity tertinggi pada produk dinyatakan sebagai produk yang memiliki kemampuan baik dalam menjaga kestabilan beratnya (Oktari, 2017). 
pH

Hasil penelitian menunjukkan bahwa suhu pemanasan, konsentrasi carbopol dan interaksi antar perlakuan berpengaruh tidak nyata $(\mathrm{P}>0,05)$ terhadap $\mathrm{pH}$ sabun cair cuci tangan. Nilai rata-rata pengukuran $\mathrm{pH}$ sabun cair cuci tangan dapat dilihat pada Tabel 7.

Tabel 7. menunjukkan bahwa suhu pemanasan dan konsentrasi carbopol berpengaruh tidak nyata terhadap $\mathrm{pH}$ sabun cair cuci tangan. $\mathrm{pH}$ sabun cair pada syarat mutu sabun cair berkisar antara 8-11 (SNI,1996). Data pengukuran $\mathrm{pH}$ terhadap sabun cair cuci tangan berkisar antara 8,50 sampai 9,10, sehingga sabun cair cuci tangan sudah memenuhi syarat

Tabel 7. Nilai rata-rata pengukuran $\mathrm{pH}$ sabun pada perlakuan suhu pemanasan dan konsentrasi carbopol.

\begin{tabular}{cccc}
\hline \multirow{2}{*}{ Konsentrasi Carbopol (\%) } & \multicolumn{3}{c}{ Suhu Pemanasan $\left({ }^{\circ} \mathrm{C}\right)$} \\
\cline { 2 - 4 } & 70 & 80 & 90 \\
\hline 1 & $8,85 \pm 0,21^{\mathrm{a}}$ & $8,80 \pm 0,14^{\mathrm{a}}$ & $9,05 \pm 0,21^{\mathrm{a}}$ \\
2 & $8,70 \pm 0,00^{\mathrm{a}}$ & $9,10 \pm 0,57^{\mathrm{a}}$ & $8,70 \pm 0,28^{\mathrm{a}}$ \\
3 & $8,80 \pm 0,14^{\mathrm{a}}$ & $8,50 \pm 0,00^{\mathrm{a}}$ & $8,55 \pm 0,07^{\mathrm{a}}$ \\
\hline
\end{tabular}

Keterangan: Huruf yang sama dibelakang nilai rata-rata menunjukkan perbedaan yang tidak nyata $(\mathrm{P}>0,05)$. Data merupakan rata-rata dari dua kelompok percobaan

\section{Alkali Bebas}

Hasil penelitian menunjukkan bahwa suhu pemanasan, konsentrasi carbopol dan interaksi antar perlakuan berpengaruh tidak nyata $(\mathrm{P}>0,05)$ terhadap alkali bebas sabun cair cuci tangan. Nilai rata-rata alkali bebas sabun cair cuci tangan dapat dilihat pada Tabel 8.

Tabel 8. Nilai rata-rata alkali bebas (\%) pada perlakuan suhu pemanasan dan konsentrasi carbopol.

\begin{tabular}{cccc}
\hline \multirow{2}{*}{ Konsentrasi Carbopol (\%) } & \multicolumn{3}{c}{ Suhu Pemanasan $\left({ }^{\circ} \mathrm{C}\right)$} \\
\cline { 2 - 4 } & 70 & 80 & 90 \\
\hline 1 & $0,02 \pm 0,00^{\mathrm{a}}$ & $0,04 \pm 0,02^{\mathrm{a}}$ & $0,04 \pm 0,02^{\mathrm{a}}$ \\
3 & $0,03 \pm 0,01^{\mathrm{a}}$ & $0,02 \pm 0,00^{\mathrm{a}}$ & $0,02 \pm 0,01^{\mathrm{a}}$ \\
\hline
\end{tabular}

Keterangan: Huruf yang sama dibelakang nilai rata-rata menunjukkan perbedaan yang tidak nyata $(\mathrm{P}>0,05)$. Data merupakan rata-rata dari dua kelompok percobaan.

Tabel 8 menunjukkan bahwa suhu pemanasan dan konsentrasi carbopol berpengaruh tidak nyata terhadap alkali bebas sabun cair cuci tangan. Alkali bebas sabun cair pada syarat mutu sabun cair maksimal $0,1 \%$ untuk $\mathrm{NaOH}$ dan maksimal $0,4 \%$ untuk KOH (SNI,1996). Data pengukuran alkali bebas terhadap sabun cair cuci tangan berkisar antara $0,02 \%$ sampai $0,06 \%$, sehingga sabun cair cuci tangan sudah memenuhi syarat.

\section{Penerimaan Keseluruhan}

Hasil penelitian menunjukkan bahwa suhu pemanasan, konsentrasi carbopol dan interaksi antar perlakuan berpengaruh tidak nyata $(\mathrm{P}>0,05)$ terhadap penerimaan keseluruhan sabun cair cuci tangan. Nilai rata-rata penerimaan keseluruhan sabun cair cuci tangan dapat dilihat pada Tabel 9.

Penilaian organoleptik panelis terhadap penilaian keseluruhan merupakan hasil penilaian terhadap hasil keseluruhan parameter organoleptik yaitu aroma, warna, kekentalan, banyak busa, kesan saat pemakaian dan kesan setelah pemakaian. Data pengujian organoleptik terhadap penilaian keseluruhan sabun cair cuci tangan berkisar antara 3,7 hingga 6,4 (netral sampai suka). Penerimaan keseluruhan sabun cair 
cuci tangan dengan nilai rata-rata tertinggi didapat pada perlakuan suhu $70^{\circ} \mathrm{C}$ konsentrasi carbopol $2 \%$ dengan nilai 6,4 , sedangakan nilai terendah didapat pada perlakuan suhu $90^{\circ} \mathrm{C}$ konsentrasi carbopol $2 \%$ dan $3 \%$ dengan nilai 3,7 .

Tabel 9. Nilai rata-rata penerimaan keseluruhan pada perlakuan suhu pemanasan dan konsentrasi carbopol.

\begin{tabular}{cc}
\hline Perlakuan & Nilai rata-rata \\
\hline $70^{\circ} \mathrm{C}$, Carbopol 1\% & $5,0 \pm 0,91$ \\
$70^{\circ} \mathrm{C}$, Carbopol $2 \%$ & $6,4 \pm 0,85$ \\
$70^{\circ} \mathrm{C}$, Carbopol 3\% & $5,1 \pm 0,86$ \\
$80^{\circ} \mathrm{C}$, Carbopol 1\% & $5,8 \pm 0,80$ \\
$80^{\circ} \mathrm{C}$, Carbopol $2 \%$ & $4,5 \pm 0,88$ \\
$80^{\circ} \mathrm{C}$, Carbopol $3 \%$ & $5,1 \pm 0,80$ \\
$90^{\circ} \mathrm{C}$, Carbopol 1\% & $5,5 \pm 0,74$ \\
$90^{\circ} \mathrm{C}$, Carbopol $2 \%$ & $3,7 \pm 1,06$ \\
$90^{\circ} \mathrm{C}$, Carbopol 3\% & $3,7 \pm 0,91$ \\
\hline Keterangan: Hasil uji organoleptik menunjukkan \\
\multicolumn{2}{c}{ pengaruh yang tidak nyata (P>0,05) }
\end{tabular}

\section{Hasil Uji Indeks Efektivitas Produk Sabun Cair Cuci Tangan}

Uji Indeks efektivitas dilakukan untuk menentukan perlakuan terbaik dalam menghasilkan produk sabun cair cuci tangan. Variabel yang diamati dalam uji indeks efektivitas ini yaitu, bobot jenis, tinggi busa, stabilitas busa, water holding capacity, $\mathrm{pH}$ sabun, alkali bebas dan penerimaan keseluruhan. Hasil uji indeks efektivitas dapat dilihat pada Tabel 10.

Perlakuan terbaik ditunjukkan dengan nilai tertinggi dari penjumlahan nilai $(\mathrm{NH})$ pada tiap variabel. Tabel 10 menunjukkan bahwa perlakuan suhu pemanasan $80^{\circ} \mathrm{C}$ dengan konsentrasi carbopol $1 \%$ mempunyai nilai terbaik yaitu 0,72 . Hal tersebut menunjukkan bahwa perlakuan suhu pemanasan $80^{\circ} \mathrm{C}$ dengan konsentrasi carbopol $1 \%$ merupakan perlakuan terbaik yang dapat menghasilkan produk sabun cair cuci tangan yang baik, sehingga dapat digunakan sebagai sediaan pembersih yang dapat digunakan setiap hari pada kulit.

\section{KESIMPULAN DAN SARAN}

\section{Kesimpulan}

Berdasarkan hasil penelitian yang dilakukan, maka dapat disimpulkan bahwa:

1. Perlakuan suhu pemanasan, konsentrasi carbopol serta interaksi antar kedua perlakuan berpengaruh sangat nyata terhadap viskositas. Perlakuan suhu pemanasan berpengaruh sangat nyata, tetapi konsentrasi carbopol dan interaksi antar perlakuan berpengaruh tidak nyata terhadap bobot jenis dan stabilitas busa. Perlakuan konsentrasi carbopol berpengaruh sangat nyata, suhu pemanasan berpengaruh nyata tetapi interaksi antar kedua perlakuan berpengaruh tidak nyata terhadap tinggi busa. Perlakuan suhu pemanasan, konsentrasi carbopol dan interaksi antar perlakuan berpengaruh tidak nyata terhadap water holding capacity, $\mathrm{pH}$, alkali bebas dan penerimaan keseluruhan

2. Perlakuan suhu pemanasan $80^{\circ} \mathrm{C}$ dengan konsentrasi carbopol $1 \%$ merupakan perlakuan terbaik yang menghasilkan produk sabun cair cuci tangan dengan karakteristik nilai viskositas $45 \mathrm{mPas}$, bobot jenis $1,01 \mathrm{~g} / \mathrm{ml}$, tinggi busa 10,70 $\mathrm{cm}$, stabilitas busa $69,98 \%$, water holding capacity $7,15 \%, \mathrm{pH} 8,80$, alkali bebas $0,04 \%$ dan penerimaan keseluruhan 5,80.

\section{Saran}

Penelitian ini masih dapat dikembangkan lebih lanjut dengan menggunakan formulasi terbaik dari hasil penelitian ini yaitu perlakuan suhu pemanasan $80^{\circ} \mathrm{C}$ dan konsentrasi carbopol $1 \%$. Penelitian selanjutnya, perlu dilakukan uji lebih lanjut mengenai umur simpan dan total cemaran mikroba pada sabun agar sabun 
menjadi lebih aman digunakan untuk keperluan sehari-hari.

\section{DAFTAR PUSTAKA}

Apgar, S. 2010. Formulasi Sabun Mandi Cair yang Mengandung Gel Daun Lidah Buaya (Aloe vera (L.) Webb.) dengan Basis Virgin Coconut Oil (VCO). Skripsi. Tidak dipublikasi. Program Studi Farmasi Fakultas Matematika dan Ilmu Pengetahuan Alam Universitas Islam Bandung, Bandung.

Ande, B. 2014. Pengaruh Penambahan Konsentrasi Carbopol 940 pada sediaan Sunscreen Gel Ekstrak Temu Giring (Curcuma Heyneana val.) Terhadap Sifat Fisik dan Stabilitas Sediaan dengan Sorbitol sebagai Humectant.Skripsi S1. Tidak dipublikasikan. Fakultas Farmasi Universitas Sanata Dharma, Yogyakarta.

Cavitch, S. M. 2001. Choosing your oils, oil properties of fatty acid. Melalui http://users.silloverlink.net/ timer/soapdesign.html. Diakses pada 4 Maret 2018.

Chastelyna, A. J. 2016. Uji Aktivitas Sabun Cair Ekstrak Daun Jati (Tectona grandis L.f.) sebagai Antibakteri terhadap Staphylococcus aureus dan Escherichia coli. Skripsi S1. Tidak dipublikasikan. Fakultas Matematika dan Ilmu Pengetahuan Alam. Universitas Negeri Semarang, Semarang.

Cottrell, I.W. dan P. Kovacs. 1980. Alginats. Di dalam: Davidson RI.(Ed.). Handbook of Water Soluble Gums and Resin. McGraw-Hill Book Co, New York.

Darlean, A. 2009. Pengaruh suhu dan lama pemanasan terhadap kerusakan minyak kelapa. Jurnal Bimafika. 1 (1): 19-26.

Departemen Kesehatan. 1995. Farmakope Indonesia. Edisi IV. Departemen Kesehatan Republik Indonesia, Jakarta.

Dyartanti, E. R., N. A. Cristi dan I. Fauzi. 2014. Pengaruh Penambahan Minyak Sawit Pada Karakteristik Sabun Transparan. Jurnal EKUILIBRIUM 13 (2): 41-44.

Gandasasmita, H.D.P. 2009. Pemanfaatan Kitosan dan Karagenan pada Produk Sabun Cair. Skripsi. Tidak dipublikasi. Program Studi Teknologi Hasil Perikanan, Fakultas Perikanan dan Ilmu Kelautan, Institut Pertanian Bogor, Bogor.

Kurnia, F. dan Ibnu H. 2010. Pembuatan Sabun Cair dari Minyak Jarak dan Soda Q Sebagai Upaya Meningkatkan Nilai Paasar Soda Q. Jurusan Teknik Kimia. Universitas Diponegoro, Semarang.

Lachman, L., Herbert A.L. dan Joseph L.K. 2008. Teori dan Praktek Farmasi Industri II, edisi Ketiga, Universitas Indonesia Press. Jakarta.

Mabrouk, S.T. 2005. Making usable quality and transparant soap. Journal of Chemical Education. 82(10):13-17.

Mitzui, T.1997. The Cosmetic Science. Elsevier Science B. V., Amsterdam.

Noveon. 2002. Neutralizing Carbopol and Pemulen Polymers in Aqueous and Hydroalcoholic Systems. http://talasonline.com/photos/msds/car bopol_ mixing.pdf, Diakses pada tanggal 25 Desember 2018.

Novianti. 2014. Formulasi Sediaan Sabun Cair Cuci Tangan Antiseptik dari Ekstrak Etanol Daun Kemangi (Ocimum americanum L.). Jurnal Ilmiah Farmako Bihari. 5(1):20870337. 
Nurlina, F. Attamimi, Rosvina dan I. Tomagola. 2013. Formulasi Sabun Cair Pencuci Tangan yang Mengandung Ekstrak Daun Kemangi (Occimum Basilicum L.). 05 (02) :119-127.

Oktari, S. A. S. E., L. P. Wrasiati dan N. M. Wartini. 2017. Pengaruh Jenis Minyak dan Konsentrasi Larutan Alginat terhadap Karakteristik Sabun Cair Cuci Tangan. Jurnal Rekayasa dan Manajemen Agroindustri. 5(2): 47-57

Piyali, G., R.G.Bhirud and V.V Kumar. 1999. Detergency and foam studies on linear alkylbenzene sulfonate and secondary alkyl sulfonate. Journal of Surfactant and Detergen. 2(4):489 - 493.

Rowe,R.C., P.J. Sheskey and M.E. Quinn. 2009. Handbook of Pharmaceutical Excipients 6 th edition. Pharmaceutical Press and American Pharmacists Association. United Kingdom. p. 441442.

Rozi, M. 2013. Formulasi Sediaan Sabun (Citrus aurantifolia) dengan Cocamid DEA sebagai Surfaktan. Skripsi. Tidak dipublikasi.Fakultas Farmasi, Universitas Muhammadiyah Surakarta, Surakarta.

Simanjuntak, T. 2000. Studi Awal Penggunaan Khitosan dari Limbah Kulit Udang, sebagai Bahan Substitusi pada Produk Hand and Body Lotion. Skripsi. Tidak dipublikasi. Departemen Teknologi Hasil Perikanan, Fakultas Perikanan dan Ilmu Kelautan, Institut Pertanian Bogor, Bogor.

Suhaime, I.H.B., M. Tripathy, M.S. Mohamed dan A.B.A Majeed. 2012. The Pharmaceutical Applications of Carbomer. Asian Journal of Pharmaceutical Sciences and Research. 2(2):1-12.

SNI 06-3532. 1994. Sabun Mandi. Dewan Standarisasi Nasional. Jakarta.

SNI 06-4085. 1996. Sabun Mandi Cair. Dewan Standarisasi Nasional. Jakarta.

Sukeksi, L., A. J. Sidabuntar dan C. Sitorus. 2017. Pembuatan Sabun Dengan Menggunakan Kulit Buah Kapuk (Ceiba petandra) Sebagai Sumber Alkali. Jurnal Teknik Kimia USU. 6(3):8-13.

Susiwi. 2009. Penilaian Organoleptik. Handout. Jurusan Pendidikan Kimia. Universitas Indonesia, Jakarta.

Wijana, S., Soemarjo dan T. Harnawi. 2009. Studi Pembuatan Sabun Mandi Cair dari Daur Ulang Minyak Goreng Bekas (Kajian Pengaruh Lama Pengadukan dan Rasio Air:Sabun Terhadap Kualitas). Jurnal Teknologi Pertanian. 10(1):54-61.

Tabel 10. Hasil uji indeks efektivitas untuk menentukan perlakuan terbaik produk sabun cair cuci tangan.

\begin{tabular}{|c|c|c|c|c|c|c|c|c|c|}
\hline \multirow{2}{*}{$\begin{array}{l}\text { Suhu } \\
\text { Pemanasan, } \\
\text { Konsentrasi } \\
\text { Carbopol }\end{array}$} & \multicolumn{9}{|c|}{ Variabel } \\
\hline & & $\begin{array}{l}\text { Bobot } \\
\text { Jenis }\end{array}$ & $\begin{array}{l}\text { Tinggi } \\
\text { Busa }\end{array}$ & $\begin{array}{l}\text { Stabilitas } \\
\text { Busa }\end{array}$ & WHC & $\mathrm{pH}$ & $\begin{array}{l}\text { Alkali } \\
\text { Bebas }\end{array}$ & $\begin{array}{l}\text { Penerimaan } \\
\text { Keseluruhan }\end{array}$ & $\begin{array}{l}\text { Jumlah } \\
\left(\sum\right)\end{array}$ \\
\hline \multirow{4}{*}{$\begin{array}{l}70^{\circ} \mathrm{C}, \\
\text { Carbopol } 1 \%\end{array}$} & (BV) & 5.00 & 4.20 & 5.80 & 5.80 & 1.80 & 2.40 & 3.00 & 28 \\
\hline & $(\mathrm{BN})$ & 0.18 & 0.15 & 0.21 & 0.21 & 0.06 & 0.09 & 0.11 & 1.00 \\
\hline & $\mathrm{Ne}$ & 0.16 & 0.33 & 0.00 & 0.80 & 0.42 & 0.92 & 0.50 & \\
\hline & $\mathrm{Nh}$ & 0.03 & 0.05 & 0.00 & 0.17 & 0.03 & 0.08 & 0.05 & 0.40 \\
\hline
\end{tabular}




\begin{tabular}{|c|c|c|c|c|c|c|c|c|c|}
\hline \multirow{2}{*}{$\begin{array}{l}\text { Suhu } \\
\text { Pemanasan, } \\
\text { Konsentrasi } \\
\text { Carbopol }\end{array}$} & \multicolumn{9}{|c|}{ Variabel } \\
\hline & & $\begin{array}{l}\text { Bobot } \\
\text { Jenis }\end{array}$ & $\begin{array}{l}\text { Tinggi } \\
\text { Busa }\end{array}$ & $\begin{array}{l}\text { Stabilitas } \\
\text { Busa }\end{array}$ & WHC & $\mathrm{pH}$ & $\begin{array}{l}\text { Alkali } \\
\text { Bebas }\end{array}$ & $\begin{array}{l}\text { Penerimaan } \\
\text { Keseluruhan }\end{array}$ & $\begin{array}{l}\text { Jumlah } \\
\left(\sum\right)\end{array}$ \\
\hline \multirow{2}{*}{$\begin{array}{l}70^{\circ} \mathrm{C}, \\
\text { Carbopol } 2 \%\end{array}$} & $\mathrm{Ne}$ & 0.16 & 0.33 & 0.48 & 0.00 & 0.67 & 0.74 & 1.00 & \\
\hline & $\mathrm{Nh}$ & 0.03 & 0.05 & 0.10 & 0.00 & 0.04 & 0.06 & 0.11 & 0.39 \\
\hline \multirow{2}{*}{$\begin{array}{l}70^{\circ} \mathrm{C}, \\
\text { Carbopol } 3 \%\end{array}$} & $\mathrm{Ne}$ & 0.00 & 0.00 & 0.52 & 0.13 & 0.50 & 0.00 & 0.54 & \\
\hline & $\mathrm{Nh}$ & 0.00 & 0.00 & 0.11 & 0.03 & 0.02 & 0.00 & 0.06 & 0.21 \\
\hline \multirow{2}{*}{$\begin{array}{l}80^{\circ} \mathrm{C}, \\
\text { Carbopol } 1 \%\end{array}$} & $\mathrm{Ne}$ & 0.53 & 0.87 & 1.00 & 0.63 & 0.50 & 0.48 & 0.79 & \\
\hline & $\mathrm{Nh}$ & 0.09 & 0.13 & 0.21 & 0.13 & 0.03 & 0.04 & 0.08 & 0.72 \\
\hline \multirow[t]{2}{*}{$\begin{array}{l}80^{\circ} \mathrm{C}, \\
\text { Carbopol } 2 \%\end{array}$} & $\mathrm{Ne}$ & 0.34 & 0.56 & 0.64 & 1.00 & 0.00 & 1.00 & 0.31 & \\
\hline & $\mathrm{Nh}$ & 0.06 & 0.08 & 0.13 & 0.21 & 0.00 & 0.09 & 0.03 & 0.60 \\
\hline \multirow{2}{*}{$\begin{array}{l}80^{\circ} \mathrm{C}, \\
\text { Carbopol } 3 \%\end{array}$} & $\mathrm{Ne}$ & 0.25 & 0.00 & 0.47 & 0.41 & 1.00 & 0.57 & 0.54 & \\
\hline & $\mathrm{Nh}$ & 0.04 & 0.00 & 0.10 & 0.09 & 0.06 & 0.05 & 0.06 & 0.40 \\
\hline \multirow{2}{*}{$\begin{array}{l}90^{\circ} \mathrm{C}, \\
\text { Carbopol } 1 \%\end{array}$} & $\mathrm{Ne}$ & 0.25 & 1.00 & 0.95 & 0.75 & 0.08 & 0.64 & 0.70 & \\
\hline & $\mathrm{Nh}$ & 0.04 & 0.15 & 0.20 & 0.16 & 0.01 & 0.06 & 0.08 & 0.68 \\
\hline \multirow[t]{2}{*}{$\begin{array}{l}90^{\circ} \mathrm{C}, \\
\text { Carbopol } 2 \%\end{array}$} & $\mathrm{Ne}$ & 0.66 & 0.67 & 0.82 & 0.09 & 0.67 & 0.98 & 0.01 & \\
\hline & $\mathrm{Nh}$ & 0.12 & 0.10 & 0.17 & 0.02 & 0.04 & 0.08 & 0.00 & 0.53 \\
\hline \multirow[t]{2}{*}{$\begin{array}{l}90^{\circ} \mathrm{C}, \\
\text { Carbopol } 3 \%\end{array}$} & $\mathrm{Ne}$ & 1.00 & 0.22 & 0.95 & 0.16 & 0.92 & 0.97 & 0.00 & \\
\hline & $\mathrm{Nh}$ & 0.18 & 0.03 & 0.20 & 0.03 & 0.06 & 0.08 & 0.00 & 0.58 \\
\hline
\end{tabular}

Keterangan : $\mathrm{Ne}=$ Nilai efektivitas

$\mathrm{BV}=$ Bobot Variabel

$\mathrm{Nh}=$ Nilai hasil $(\mathrm{Ne} \times \mathrm{BN})$

$\mathrm{BN}=$ Bobot 